\title{
A Survey on the Relationship between Self/Functional Congruities on Customer's Switching Intention
}

\author{
Reza saleki ${ }^{1}$, Mohsen Saki ${ }^{2}$, Mohammad Javad Nekooei ${ }^{3 *}$ \\ 1,2 International Business School, Universiti Teknologi Malaysia, Kuala Lumpur, Malaysia \\ ${ }^{3}$ Department of Mechanical Engineering, Safashahr branch, Islamic Azad University, Safashahr, Iran
}

\begin{abstract}
The effect of self-congruity and functional congruity on switching intention is one new issue that marketers are encountering. The purpose of this study is to review the relationship among four dimensions of self-congruity (actual, ideal, social and ideal social congruity) and functional congruity with switching intention. To deepen the understanding of customers' switching decision formation, the researchers attempted to develop a switching intention model, consisted of self-image dimensions (actual, ideal, social, and ideal social self-congruity) and functional congruity. At the end of this paper, some new issues are recommended for the future research in this field.
\end{abstract}

Keywords: Self-congruity, Actual Ideal, Social and Ideal Social Congruity, Functional Congruity, Switching Intentions

\section{Introduction}

Functional congruity is known as the existed match between the ideal expectation of the consumer from product aspects and their perception of how the product is considered (Kressmann et al., 2006). Functional congruity and self-congruity may be considered as the competing theories (Mannetti et al., 2004) but some of the experts have shown that these two theories are completing each other and also the integration between them define the product choice and preferences in a more proper way (Sirgy et al., 2005).

The existed congruence between the product image and self-image will lead to specific product preference as well as purchase behaviors due to the fact that individuals are eager to act congruent with their own selfimage (Federico et al., 2007).Various self-congruities of the disciplines were mentioned. (Rosenberg et al. (1989)) noted that there were a lot of self-concept studies in psychoanalysis, psychology and sociology. The most important intention of an individual action is maintaining and increasing their symbolic self that is the fact that they like to participate in behaviors and actions that show their self-image in the most proper way. The person who owns a Lamborghini car for example, may be known as the hot, young and rich person.

The mentioned recognition demonstrates the image of the product user. While a consumer observes herself/himself as a young and rich person, this perception will be the self-concept of consumer. The existed match between image of product user and self-concept of consumer shows the self-congruity. The attitude of individuals related to products could be impacted by the self-congruity in such a way that the more the selfcongruity, the higher the favorable behavior related to products. The consumer intention for switching is one of the most important concerns to the service providers. For instance, Grace and O'Cass (2004) noted that because of negative impact of switching intention for reducing the market share and profitability of bottom line, the service firms would more and more focus on the clients that tend to quit and make their patronage in another place.

Previously, several studies in the field of consumer behavior investigated the role of self-image, which consists of two dimensions: self-congruity and functional congruity. Self-congruity consists of four dimensions but rare studies have investigated the all four dimensions in relationship with functional congruity in one particular study. On the other hand, while the role of switching intention is quite apparent in marketing and consumer behaviors, rare studies in recent years have examined the relationship between self-image and switching intention (Han and Hyun, 2012). One of the contributions of this study that makes it different from previous works is that it reviews the relationship between both self and functional congruity with switching intention while the previous studies only focused on the effect of self-congruity on switching intention.

\section{Research questions}

1. Is there a negative significant relationship between four dimensions of self-congruity (actual, ideal, social and ideal social self-congruity) and switching intention?

2. Is there a positive significant relationship between functional congruity and switching intention?

3. Is there a positive significant relationship between four dimensions of self-congruity (actual, ideal, social and ideal social self-congruity) and functional congruity? 


\section{Research objectives}

1. To review the relationship between four dimensions of self-congruity (actual, ideal, social and ideal social self-congruity) and switching intention.

2. To review the relationship between functional congruity and switching intention.

3. To review the relationship between four dimensions of self-congruity (actual, ideal, social and ideal social self-congruity) and functional congruity.

From academic perspective, this study can broad the literature in the effect of self and functional congruity on switching intention. In addition to rare studies on moderating role of customer involvement and switching cost in relationship between self and functional congruity with switching intention, this study can make a comprehensive perspective for academician who are interested in doing research in this area. In overall, this study reviews two relationships. First relationship between self-congruity dimensions (actual, ideal, social and ideal social self-congruity) and functional congruity. Second relationship between functional congruity and switching intention.

\section{Literature Review}

This section comprises of literatures on current research topic in order to develop a theatrical framework. In this study, researchers will use secondary literature resources as reference such as books and journals. This section consists of three main topics together with the subtopics as well. The main topics are as follows: Selfcongruity, Functional congruity, and conceptual framework. Self-congruity has been divided into four subtopics including: (1) actual self-congruity (2) ideal self-congruity (3) social self-congruity (4) ideal social selfcongruity. Each variable is explained fully in following parts.

\section{Self-congruity}

The foundation of theory for self-congruity is the fact that the image of product is assessed according to interpretations from consumers. It means that if the customer has the reinforced self-concept from product then the purchase decision will be done (Fox et al., 2004). Based on Kressmann et al. (2006), the amount of consistency among self-concept of the consumers and brand is known as self-image / product image congruity in which consumer behavior will be defined through the cognitive matching among valued attributes of brand (Johar and Sirgy, 1991).

Self-concept which is also known as self-image was explained as total individual feelings and thoughts referred to themselves as the objects (Scherrer et al., 1995). Previous investigations defined the self-concept as a construct which is not dimensional and being treated like actual self-concept but the later investigations defined it as a construct with two components which are ideal and actual self-concepts (Lodish et al., 1988). Johar and Sirgy (1991), worked beyond the dual dimensions and provided the construct with many dimensions for the selfconcept which not only has ideal and actual self-concepts but contains the social self-concept as well. Based on Johar and Sirgy (1991), the self-concept is known as the construct with many dimensions which has main components such as ideal self-concept, actual self-concept, ideal social self-concept and social self-concept. In this multidimensional developed framework, actual self-concept is the way people actually perceive themselves and the ideal self-concept is the way that people like to consider themselves.

\section{Actual Self-congruity}

People have the independent dominant self-construal and therefore they like to be separated from other (Yamada and Singelis, 1999). On the other side, collectivists like people from East Asian cultures like to develop harmony with other ones and define their similarity points and conformity to other people (Hammadeh et al., 2001).

In the other researches, Kressmann et al. (2006), revealed that purchase motivation of the consumers is impacted by the self-image congruity in such a way that they choose the products which are compatible with their self-image. Sirgy (1985) mentioned that congruence between self-image and product image will increase the positive behaviors from customers and also their attitudes for certain products and also will impact the product preference and purchase intention.

Litvin and Goh (2002) mentioned that self-congruity would enhance both the positive attitude of the customers for a product and the likelihood to purchase. It was also noted that post consumption loyalty and the pre consumption assessments are impacted by the self-image congruity (Kressmann et al., 2006). Moreover, Mannetti et al. (2004), stated that purchase behavior of people and their preferences are congruent into their own self-image. Here the relationship among customer attitude and self-congruity is going to be tested. Sirgy and Su (2000) provided an integrated model for explaining the impacts of self-congruity related to travel behavior. Their proposed theoretical model noted the fact that travel behavior will not be impacted just by self-congruity but rather the other elements are crucial for defining the travel behavior mainly the functional type or the existed 
match among the features of utilitarian related to destination and degree to which they can match the expectations of visitors. Therefore, Based on the above discussion, following hypothesises are proposed:

H1a: There is a negative significant relationship between actual self-congruity and switching intention.

H2a: There is a positive significant relationship between ideal self-congruity and functional congruity.

\section{Ideal Self-congruity}

One aspect from self-image that has achieved a lot of concentration is ideal self-image. Ideal self-image or called as self a person wants to be will contain the personal aspiration and also societal norms and parental expectations(Zigler and Glick, 2001). Ideal self-image was shown as the place for oneself imagining inside new roles, for developing objectives and also designing methods of getting positive end states as well (Markus and Nurius, 1986). The empirical pros mentions that people who have more ideal self-image will be adjusted better compare to the ones who have lower ideals. More scholastic achievement, more frustration tolerance, higher satisfaction recovery and also improved behavioral conduct after the life crisis all are relevant to more ideal selfimage (Sladen, 1989).

The notion that stated the self-concept image may have vital variations. (Barger, 1974). He stated that the exited relationship between product preference and self-concept might be changed based on various product classifications because of various types of self-concept like ideal and actual self that are contained within assessment. For instance, congruence between product concept and actual self-concept might not be highly significant because the customers do not like to define themselves.

Within the context of country club, Bäck and Schwefel (1993), understood that image congruence remarkably is related to increasing the satisfaction of the club members as well as behavioral intentions. Also, Meric et al. (2008), explained that the hotel clients ideal and social image congruencies lead to favorable decision makings related to the hotel such as recommend and revisit of that hotel. Also even though the direct impact of image congruence for trust was not evaluated, Ramalho-Santos et al. (2002) in his research about new distribution channels, recognized the fact that related variables to the corporative image remarkably impact the customer trust into a certain website. The experts agree that the image of a firm is a crucial effective element for developing the customer trust and could be known as the main device for trust management in service sector (Flavian et al., 2005). The image of the firm that is a remarkable effective factor for the customer trust (Flavián and Guinalíu, 2006) and self-image of them are vital aspects of the image congruence as the match concept (Sirgy, 1985). According to all these, following hypotheses are proposed:

$\mathrm{H} 1 \mathrm{~b}$ : There is a negative significant relationship between ideal self-congruity and switching intention.

$\mathrm{H} 2 \mathrm{~b}$ : There is a positive significant relationship between ideal self-congruity and functional congruity.

\section{Social Self-congruity}

The existed logic behind the consistency and social approval could be applicable well to the hotel clients along with the feeling that they will have a powerful affection relationship to that hotel and also they have similar values, attitudes, beliefs and the other behavioral patterns with other members (Rowley). So, consumers who have more ideal social and social congruent with people who are typical members will be more satisfied and also more loyal to their own club.

Individuals like to act in a way that is congruent with how other people perceive them which is called social image congruence due to the desire for having social consistency. It means that the social image congruence will satisfy need of social consistency and the ideal social image congruence fulfills the needs of social approval. At the time that services/products are employed for enhancing the ideal social and social image congruencies, their consumers will be satisfied and become loyal to them by satisfying the needs of consistency and social approval.

A lot of studies mentioned that positive impact of social self-congruity for the customer behavior in previous studies of the marketing (Hogg et al., 2000) as well as service (Back et al., 2005). For instance the social selfcongruity will influence the hotel guest's functional attribute in a positive way(Back et al., 2005). In addition, Jamal and Goode (2001) realized that people who have more social self-congruity will be highly satisfied compared to those who have less image congruence in market of jewelry. Furthermore, the social self-congruity is the good predictor for loyalty to store and the willingness of customers for buying from that store (Sirgy et al., 1991). Generally, the customers will more likely to have good attitudes and also purchase intentions related to brands/products (Graeff, 1997). Therefore, the following hypothesis is proposed:

H1c: There is a negative significant relationship between social self-congruity and switching intention.

$\mathrm{H} 2 \mathrm{c}$ : There is a positive significant relationship between social self-congruity and functional congruity.

\section{Ideal Social Self-congruity}

The individuals will be motivated to act in ways that make other people think high about them. All of the actions inconsistent with ideal social self-image result in social disapproval. So, individuals like to act consistent with their own ideal social self-image in order to get the positive feedback from other ones. Consider an upscale 
shopper that does not like to be seen within discount store. They might think about their neighbors and friends because they think that these neighbors and friends might believe less about them.

The impact of ideal social self-congruity related to customer behavior was recorded in many investigations conducted in both of the retail stores and consumer goods. Related to consumer products, many investigations shown that there is a relationship between the ideal social self-image and product user image which provides a proper ownership or product (Sirgy, 1982). Sirgy and Samli (1985) and Sirgy et al. (1991) have revealed impacts of ideal social self-congruity related to retail patronage.

Previous investigations generally concentrated on two different dimensions of ideal and actual self-image instead of other two available dimensions of ideal and social self-image. Based on Kressmann et al. (2006), a person has both of the social consistency needs and social approval needs. To fulfill the social approval need, the person is going to be in the consistent manner with her or his significant other perception of her or him to achieve the approval and avoid the disapproval. In addition, a person likes to act in such ways related to how other people will perceive her or him due to the need for the social consistency. The social congruence will activate the desire for social consistency and also the ideal social congruence will activate the social approval need (Kressmann et al., 2006). So, these ideal and social congruencies will impact the person's decision making process and post/pre consumption behaviors (Back et al., 2005).Based on the above discussion, the following hypotheses are proposed: intention.

H1d: There is a negative significant relationship between ideal social self-congruity and switching

H2d: There is a positive significant relationship between ideal social self-congruity and functional congruity.

\section{Functional Congruity}

The functional congruity is the match among beliefs of the consumers related to brand utilitarian aspects, like performance and consumer attributes which is referent. Referent, like ideal aspects, is the used criteria for evaluating the actual performance dimensions of brand. For instance, a certain brand for toothpaste might be assessed with a series of utilitarian features. For example freshening breath, preventing cavities, tasting good and whitening teeth. Consumers might have the standards or referent points as their ideal that is used for judging the related goodness from perceived features. The more the congruence among consumer's utilitarian beliefs related to a certain brand, the more having the attitudes which are positive (Sirgy et al., 1991). Researchers of expectancy value note that the positive attitude is when the evaluation object is considered to own some characteristics that are valued positively.

The functional congruity is based on the product's considered functional features relevant to customer's desired features of performance. The functional destination of the tourist destination is identified by the way in which destination fulfills the tourist aspiration amount related to destination performance (Sirgy and Su, 2000). It means that the expected performance or the utilitarian of destination related features affect the functional congruence and not the valued or symbolic aspects. The utilitarian, according to performance destination features, tries to fulfill the most important holiday requirements of the tourists like comfort, relaxation, security, safety, accessibility and convenience.

The previous investigations related to field of hospitality focused the functional attributes role for defining the future behavior of customers (Prendergast et al., 2002). Eliwa et al. (2006), realized that the restaurant aspects are the main elements for the customers in order to define if they will patronize that restaurant. Adare $e t$ al. (2008), mentioned that the consumers demonstrate positive behavior while the service of restaurant fulfills their needs in some features like employee performance, food quality, environment and the other ones. These outcomes focused the need for studying functional congruity levels that affect the future behaviors and customer attitudes within the coffee shop environment. Clients from branded coffee shops try to match different functional features with their actual experience and expectations; these aspects are the premium prices, gourmet coffee drinks and the relaxed atmosphere of the store etc. Therefore, the following hypothesis is proposed:

H3: There is a negative significant relationship between functional congruity and switching intention.

\section{Conceptual Framework}

The conceptual framework shown in Figure 1 illustrates the relationships among study variables according to the previous researches that were discussed in the literature review. The framework has two main features. First, it examines the links among self-congruity dimensions (actual, ideal, social and ideal social congruity), and switching intention. Second, the framework examines the relationship between functional congruity and switching intention. 
Self-congruity Dimensions

Actual self-congruity

Ideal self-congruity

Social self-congruity

Ideal Social self-congruity

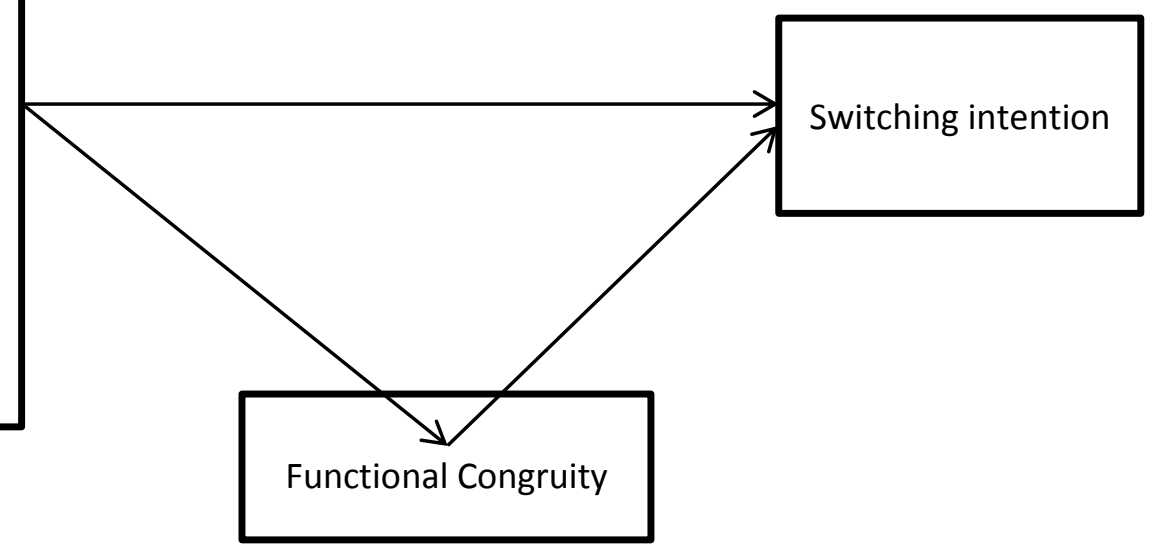

Figure 1: Conceptual Framework

\section{Methodology}

This study has two main purposes. First, investigating the relationship among self-congruity dimensions (actual, ideal, social and ideal social congruity) and switching intention. Second, surveying the relationship among self-congruity dimensions (actual, ideal, social and ideal social congruity) and functional congruity. In this section, the methodology that can be used in testing the relationship between the variables is explained in detail.

\section{Variables and Measures}

This study consists of six variables, six independent variables and one dependent variable. Independent variables consist of actual self-congruity, ideal self-congruity, social self-congruity, ideal social self-congruity and functional congruity. Dependent variable is switching intention.

\section{Dependent Variable}

a. $\quad$ Switching Intention

Items for measuring switching intention will be adapted from Chih et al. (2012). The scale is consisted of four items. Seven point likert scale will be used which measures from 1 = "strongly disagree" to $7=$ "strongly agree". Table 3.1 shows items for measuring the switching intention variable.

Table 3.1: Measurement items of switching intention

\begin{tabular}{|l|l|l|}
\hline \multicolumn{2}{|c|}{$\begin{array}{c}\text { Switching Intention } \\
\text { Definition: Switching intention refers to propensity to terminate the primary supplier (buyer-seller) } \\
\text { relationship. }\end{array}$} & Source \\
\hline No & \multicolumn{1}{c|}{ Items } & Chih et al. \\
\hline 1. & In the near future, I intend to intensify my efforts to find a better hotel. & (2012) \\
\hline 2. & In the last year, I have considered seriously switch to other hotels. & \\
\hline 3. & I have decided to stay less in this hotel in the future. & \\
\hline 4 & I think other hotels can offer better service. & \\
\hline
\end{tabular}

\section{Independent Variable}

a. Self-congruity dimensions

In this research, key measurements of constructs are borrowed from the past studies. The research tries to employ one of the two main approaches for measuring self-congruity (Sirgy et al., 1997). First approach employs a formula of gap scoring in order to compete with the self-concept and perceived image of product measurement (Johar and Sirgy, 1991). Next approach will capture directly the self-congruence measures. It tries to be highly valid and also predictive for evaluating the consumer behavior (Kressmann et al., 2006). This research will use the second approach for measuring the ideal, actual, ideal social and social self-congruity. The self-congruity is assessed by using scenario direction and twelve statements of self-congruence. The mentioned 
variables use a seven point rating scale which ranges from $1=$ "strongly disagree" to 7 = "strongly agree". Participants will be all instructed for responding the statements of self-congruent.

Items for measuring actual and ideal self-congruity have been adapted from Sirgy and Su (2000). For measuring social and ideal social self-congruity items have been adapted fromHan and Hyun (2012). Table 3.2 shows the items for dimensions of self-congruity.

Table 3.2: Measurement items of self-congruity dimensions

\begin{tabular}{|c|c|c|}
\hline \multicolumn{3}{|c|}{ actual self-congruity refers to how people see themselves. } \\
\hline No & Item & Source \\
\hline 1. & The image of the typical customer of this hotel is similar to how I am. & \multirow{4}{*}{$\begin{array}{l}\text { Sirgy and } \mathrm{Su} \\
(2000)\end{array}$} \\
\hline 2. & The image of the typical customer of this hotel is similar to how I see myself. & \\
\hline 3. & The image of the typical customer of this hotel is similar to how others believe that I am. & \\
\hline 4. & The image of the typical customer of this hotel is similar to how others see me. & \\
\hline & $\begin{array}{l}\text { Definition: Ideal self-congruity refers to how people would like to see themselves. } \\
\text { Ideal Self-congruity }\end{array}$ & \multirow{5}{*}{$\begin{array}{l}\text { Sirgy and } \mathrm{Su} \\
(2000)\end{array}$} \\
\hline 5. & "The image of the typical customer of this hotel is similar to how I would like to be". & \\
\hline 6. & $\begin{array}{l}\text { "The image of the typical customer of this hotel is similar to how I would like to see } \\
\text { myself." }\end{array}$ & \\
\hline 7. & $\begin{array}{l}\text { "The image of the typical customer of this hotel is similar to how I would like others to } \\
\text { see me." }\end{array}$ & \\
\hline \multirow[t]{2}{*}{8.} & $\begin{array}{l}\text { "The image of the typical customer of this hotel is similar to how I ideally like to be seen } \\
\text { by others." }\end{array}$ & \\
\hline & $\begin{array}{l}\text { Social Self-congruity } \\
\text { Definition: Social self-congruity refers to how people think others see themselves. }\end{array}$ & \multirow[t]{2}{*}{$\begin{array}{l}\text { Han and Hyun } \\
\text { (2012) }\end{array}$} \\
\hline \multirow[t]{2}{*}{9.} & The image of the typical customer of this hotel is similar to how I am. & \\
\hline & $\begin{array}{l}\text { Ideal Social Self-congruity } \\
\text { Definition: Ideal social self-congruity refers to how people would like others to see } \\
\text { themselves. }\end{array}$ & \multirow[t]{4}{*}{$\begin{array}{l}\text { Han and Hyun } \\
(2012)\end{array}$} \\
\hline 10. & $\begin{array}{l}\text { "The typical customer at this restaurant has personality characteristics similar to mine as } \\
\text { perceived by others." }\end{array}$ & \\
\hline 11. & $\begin{array}{l}\text { "The typical customer at this restaurant has an image similar to how I would like other } \\
\text { people to see me." }\end{array}$ & \\
\hline 12. & $\begin{array}{l}\text { "The typical customer at this restaurant is very much the kind of person I would like } \\
\text { other people see me as." }\end{array}$ & \\
\hline
\end{tabular}

\section{b. Functional Congruity}

Items for measuring functional congruity are adopted from Benítez et al. (2007). The scale is consisted of five items. Five point likert scale was used which measured from $1=$ "very poor" to 5 = "very good". Table 3.3 shows items for the Functional congruity variable. Respondents will be asked to compare their expectations in the next steps of future researches.

Table 3.3: Measurement items of functional congruity

\section{Functional Congruity}

Definition: "Functional congruity refers to the match between the perceived functional or performance characteristics and the consumer's desired or important functional characteristics"

\begin{tabular}{|l|l|l|}
\hline No & Item & \multirow{2}{*}{ Source } \\
\hline 1. & How do you evaluate reception desk? & \multirow{2}{*}{ Be (2007) } \\
\hline 3. & How do you evaluate room cleaning? & \\
\hline 4. & How do you evaluate room maintenance? & \\
\hline 5. & How do you evaluate bar service? & \\
\hline 6. & How do you evaluate hotel's cleaning pool and garden area? & \\
\hline
\end{tabular}

\section{Questionnaire Design}

The questionnaire will consist of four sections and each section will measure respondents' ideas and perceptions towards each variable studied. Section A will consist of twelve questions for measuring respondents' opinions toward self-congruity dimension (actual self-congruity, ideal self-congruity, social self- 
congruity and ideal social self-congruity). This section will consist of four questions for actual self-congruity, four questions for ideal self-congruity, one question for social self-congruity and three questions for ideal social self-congruity. Section B will consist of six questions to discover the respondents' opinions toward functional congruity. Section $\mathrm{C}$ will comprise of four questions for measuring switching intention.

\section{Summary}

To deepen the understanding of customers' switching decision formation, the present study attempts to develop a switching intention model, consisted of self-image dimensions (actual, ideal, social, and ideal social self-congruity) and functional congruity. To assess study variables, validated measures in previous researches were adopted and modified to be appropriate in the present study setting.

\section{Future Work}

This study has several recommendations for future research work. First, Jones et al. (2000) concluded that switching cost moderates the relationship between satisfactions and repurchase intention. Switching barriers make customer defection difficult or costly. Therefore, future studies can apply the moderator used by Jones et al. (2000) in their study model. Sirgy and Su (2000) proposed that the relationship between self-congruity, functional congruity, and travel behavior might be moderated by customer involvement. Therefore, future work can apply the moderators proposed by Sirgy and Su (2000).

\section{Reference}

[1]. Adare, A., Afanasiev, S., Aidala, C., Ajitanand, N., Akiba, Y., Al-Bataineh, H., et al. (2008). Suppression Pattern of Neutral Pions at High Transverse Momentum in $\mathrm{Au}+\mathrm{Au}$ Collisions at sqrt $\left[\mathrm{s}_{-}\{\mathrm{NN}\}\right]=200 \mathrm{GeV}$ and Constraints on Medium Transport Coefficients. Physical review letters. 101(23), 232301.

[2]. Athar, M., Back, J. H., Tang, X., Kim, K. H., Kopelovich, L., Bickers, D. R., et al. (2007). Resveratrol: a review of preclinical studies for human cancer prevention. Toxicology and applied pharmacology. 224(3), 274-283.

[3]. Back, B., Baker, M., Ballintijn, M., Barton, D., Becker, B., Betts, R., et al. (2005). The PHOBOS perspective on discoveries at RHIC. Nuclear Physics A. 757(1), 28-101.

[4]. Bäck, T., and Schwefel, H.-P. (1993). An overview of evolutionary algorithms for parameter optimization. Evolutionary computation. 1(1), 1-23.

[5]. Barger, V. (1974). Proceedings of the XVII International Conference on High Energy Physics, London, 1974.

[6]. Benítez, J. M., Martín, J. C., and Román, C. (2007). Using fuzzy number for measuring quality of service in the hotel industry. Tourism Management. 28(2), 544-555.

[7]. Chih, W.-H., Wang, K.-Y., Hsu, L.-C., and Cheng, I.-S. (2012). From disconfirmation to switching: an empirical investigation of switching intentions after service failure and recovery. The Service Industries Journal. 32(8), 1305-1321.

[8]. Eliwa, H., Kimura, J.-I., and Itaya, T. (2006). Late Neoproterozoic Dokhan Volcanics, North Eastern Desert, Egypt: geochemistry and petrogenesis. Precambrian Research. 151(1), 31-52.

[9]. Federico, C. M., Jost, J. T., Pierro, A., and Kruglanski, A. W. (2007). The Need for Closure and Political Attitudes: Final Report for the ANES Pilot. ANES Pilot Study Report, No. nes01190 (http://www. electionstudies. org/resources/papers/Pilot2006/nes011904. pdf, letzter Zugriff 11.05. 2010).

[10]. Flavián, C., and Guinalíu, M. (2006). Consumer trust, perceived security and privacy policy: three basic elements of loyalty to a web site. Industrial Management \& Data Systems. 106(5), 601-620.

[11]. Flavian, C., Guinaliu, M., and Torres, E. (2005). The influence of corporate image on consumer trust: A comparative analysis in traditional versus internet banking. Internet Research. 15(4), 447-470.

[12]. Fox, C. S., Evans, J. C., Larson, M. G., Kannel, W. B., and Levy, D. (2004). Temporal Trends in Coronary Heart Disease Mortality and Sudden Cardiac Death From 1950 to 1999 The Framingham Heart Study. Circulation. 110(5), 522-527.

[13]. Grace, D., and O'Cass, A. (2004). Examining service experiences and post-consumption evaluations. Journal of Services Marketing. 18(6), 450-461.

[14]. Graeff, T. R. (1997). Consumption situations and the effects of brand image on consumers' brand evaluations. Psychology \& Marketing. 14(1), 49-70.

[15]. Hammadeh, M., Georg, T., Rosenbaum, P., and Schmidt, W. (2001). Association between freezing agent and acrosome damage of human spermatozoa from subnormal and normal semen. Andrologia. 33(6), 331-336.

[16]. Han, H., and Hyun, S. S. (2012). Image congruence and relationship quality in predicting switching intention: Conspicuousness of product use as a moderator variable. Journal of Hospitality \& Tourism Research.

[17]. Hogg, M. K., Cox, A. J., and Keeling, K. (2000). The impact of self-monitoring on image congruence and product/brand evaluation. European Journal of Marketing. 34(5/6), 641-667.

[18]. Jamal, A., and Goode, M. M. (2001). Consumers and brands: a study of the impact of self-image congruence on brand preference and satisfaction. Marketing Intelligence \& Planning. 19(7), 482-492.

[19]. Johar, J. S., and Sirgy, M. J. (1991). Value-expressive versus utilitarian advertising appeals: when and why to use which appeal. Journal of advertising. 20(3), 23-33.

[20]. Jones, B. M., Redmond, W., Taleghani, A., Little, R. A., Sawicki, M., Kirkland, W., et al. (2009). Davis et al.

[21]. Kaveh, J., and Saleki, R. (2013). New Brand Creation and Power of Alliance Strategy. Australian Journal of Basic \& Applied Sciences. 7(8).

[22]. Kressmann, F., Sirgy, M. J., Herrmann, A., Huber, F., Huber, S., and Lee, D.-J. (2006). Direct and indirect effects of self-image congruence on brand loyalty. Journal of Business Research. 59(9), 955-964.

[23]. Lodish, H., Terazono, K., Yamamoto, H., Takasawa, S., Shiga, K., Yonemura, Y., et al. (1988). Transport of secretory and membrane glycoproteins from the rough endoplasmic reticulum to the Golgi. A rate-limiting step in protein maturation and secretion. Transport. 263(5).

[24]. Markus, H., and Nurius, P. (1986). Possible selves. American psychologist. 41(9), 954. 
[25]. Meric, I., Han, M. Y., Young, A. F., Ozyilmaz, B., Kim, P., and Shepard, K. L. (2008). Current saturation in zero-bandgap, topgated graphene field-effect transistors. Nature nanotechnology. 3(11), 654-659.

[26]. Prendergast, G., Ho, B., and Phau, I. (2002). A Hong Kong view of offensive advertising. Journal of Marketing Communications. $8(3), 165-177$

[27]. Ramalho-Santos, M., Yoon, S., Matsuzaki, Y., Mulligan, R. C., and Melton, D. A. (2002). " Stemness": transcriptional profiling of embryonic and adult stem cells. Science. 298(5593), 597-600.

[28]. Reimers, B., Schlüter, M., Castriota, F., Tübler, T., Corvaja, N., Cernetti, C., et al. (2004). Routine use of cerebral protection during carotid artery stenting: results of a multicenter registry of 753 patients. The American journal of medicine. 116(4), 217-222.

[29]. Rowley, C. BEYOND CRONYISM: IN PURSUIT OF DEEP TRUST.

[30]. Scherrer, P., Bogart, R., Bush, R., Hoeksema, J., Kosovichev, A., Schou, J., et al. (1995). The solar oscillations investigationMichelson Doppler imager. Solar Physics. 162(1-2), 129-188.

[31]. Saleki, R. (2014). Assessing the effect of self-congruity and functional congruity on switching intention in Malaysian hotel industry. Unpublished Master thesis. Universiti Teknologi Malaysia.

[32]. Saleki, R., Saki, M., and Nikkhah, H. (2013). Investigating effect of self-image on customer's attitude in Malaysian restaurant industry. European Journal of Scientific Research. 162(5), 328-349.

[33]. Sirgy, M. J. (1982). Self-concept in consumer behavior: A critical review. Journal of consumer research, 287-300.

[34]. Sirgy, M. J. (1985). Using self-congruity and ideal congruity to predict purchase motivation. Journal of business Research. 13(3), 195-206.

[35]. Sirgy, M. J., Grewal, D., Mangleburg, T. F., Park, J.-o., Chon, K.-S., Claiborne, C., et al. (1997). Assessing the predictive validity of two methods of measuring self-image congruence. Journal of the academy of marketing science. 25(3), 229-241.

[36]. Sirgy, M. J., Johar, J., Samli, A. C., and Claiborne, C. (1991). Self-congruity versus functional congruity: predictors of consumer behavior. Journal of the Academy of Marketing Science. 19(4), 363-375.

[37]. Sirgy, M. J., and Samli, A. C. (1985). A path analytic model of store loyalty involving self-concept, store image, geographic loyalty, and socioeconomic status. Journal of the Academy of Marketing Science. 13(3), 265-291.

[38]. Sirgy, M. J., and Su, C. (2000). Destination image, self-congruity, and travel behavior: Toward an integrative model. Journal of Travel Research. 38(4), 340-352.

[39]. Yamada, A.-M., and Singelis, T. M. (1999). Biculturalism and self-construal. International Journal of Intercultural Relations. 23(5), 697-709.

[40]. Zigler, E., and Glick, M. (2001). A developmental approach to adult psychopathology. Wiley. 